\title{
Collective Identity and the History of Communication Studies
}

\section{Maria Löblich}

Frei Universität Berlin, maria.loeblich@fu-berlin.de

THIS ESSAY EXPLORES the role of collective identity in the history of communication studies. Collective identities are ideas about social belonging and values, about who we are and who the others are. Collective identities involve ideas of homogeneity and difference and involve issues of power and resource distribution. ${ }^{1}$ There are at least two aspects of the historical relation between communication studies and collective identity: (1) The history of communication studies is linked to public communication, where collective identities are discussed, defined, and ascribed to groups or collectives in society or in the world. Scholarly work in the past studied, tacitly reproduced, or questioned collective identity constructs made by the media. (2) Communication studies worldwide have been carriers of a "weconsciousness," ${ }^{2}$ precondition for academic community-building and legitimacy work. Moreover, communication studies have been the object of identity ascriptions from the outside.

Some historians and sociologists have criticized the concept of collective identity for the ideologically charged, manipulative use of this term in the twentieth century, for the lack of a theory, and for suggesting collective identity is something "natural."3 In communication studies, some have noted critically that some historical accounts have been whitewashing and mystifying the field's historiography. According to Simonson and Park, "representatives of the dominant paradigms offered their own historical accounts" when defining the significance of classic works or great male scholars. ${ }^{4}$ Wahl-Jorgensen has written about the "tale of coherence" that those accounts provided by glossing over separations and differences which were typi-

History of Media Studies, vol. 1, 2021

\begin{abstract}
Maria Löblich, "Collective Identity and the History of Communication Studies," History of Media Studies 1 (2021), https://doi.org/ 10.32376/d895aoea.cf521edc.
\end{abstract}

(c) (1) (5)
${ }^{3}$ Eisenstadt and Giesen, "The Construction of Collective Identity," 74 .

\footnotetext{
${ }^{4}$ Peter Simonson and David W. Park, "Introduction. On the History of Communication Study," in The International History of Communication Study, eds. Peter Simonson and David W. Park (New York: Routledge, 2016), 4-5; cf. Jefferson Pooley and David W. Park, "Introduction," in The History of Media and Communication Research. Contested Memories, eds. David W. Park and Jefferson Pooley (New York: Lang, 2008), $1-4$.
} 
cal for the development of "the messy field of mass communication study." 5

What is this "plastic phrase," ${ }^{\prime 6}$ collective identity, worth? This essay does not intend to prescribe a disciplinary collective identity but rather to suggest reflecting on the analytical potential of this concept. Regarding theory, this essay is based on the sociology of Pierre Bourdieu and the works of Jan Assmann, the German Egyptologist. Their theoretical tools (personal and collective identity, cultural memory, symbolic power, habitus, capital, and field) lead to an understanding of collective identity as a social construct that contains selected and formed ideas about a collective as well as its memories of the past. Collective identities are constructed in symbolic practices, rooted in habitus-capital-field constellations, and linked to power. They may lead to inclusion and exclusion. Collective identity reveals how communication studies were historically tied to symbolic systems in society and what degree of autonomy they had. 7 The aim of the historiography suggested here is to determine which symbolic formation of a "we" and "the others" the discipline has contributed to over the course of time. ${ }^{8}$ This applies to groups in society and to the discipline itself.

Studying the exclusion or marginalization of theories and groups in the history of the field helps to discover and recover forgotten or marginalized alternative ways of thinking and approaches to media and communication. Moreover, it enables us to reflect on the discipline's involvement in political and manipulatory uses of the normative concepts of collective identities. An example of such an involvement is German communication studies and its past in National Socialism. ${ }^{9}$

The concept of collective identity is not a typical concept deployed in research on inclusion and exclusion in the discipline-for example, in feminist and cosmopolitan approaches. But it could complement and, to some extent, bundle such perspectives because there is the shared concern to reveal and discuss "asymmetries for exclusion or inclusion of scholarly voices" and other voices in society. ${ }^{10}$

\section{Historical Perspectives on Collective Identity and Communication Studies}

There are at least two ways the usage of the term collective identity can be distinguished. In the first, which involves reconstructive understanding, collective identity describes the idea a group develops of itself by identifying similar self-views and worldviews, experiences, and expectations on the part of single members of the group. In the second, there is a prescriptive use of the term. It ascribes common

History of Media Studies, vol. 1, 2021
${ }^{5}$ Karin Wahl-Jorgensen, "Rebellion and Ritual in Disciplinary Histories of U.S. Mass Communication Study: Looking for 'The Reflexive Turn,' " Mass Communication $\mathcal{E}$ Society 3, no. 1 (2000): 90, 98 .

${ }^{6}$ Dietmar Rost, "Reviewed Work(s): Kollektive Identität. Heimliche Quellen einer unheimlichen Konjunktur by Lutz Niethammer," Historical Social Research. 28, no. 4 (2003): 188.
${ }^{9}$ Christopher Simpson, "Elisabeth Noelle-Neumann's 'Spiral of Silence' and the Historical Context of Communication Theory," Journal of Communication 46 (1996).

\footnotetext{
${ }^{10}$ Hanan Badr and Sarah Anne Ganter, "Towards Cosmopolitan Media and Communication Studies: Bringing Diverse Epistemic Perspectives into the Field." Global Media Journal, German Edition 11, no. 1 (2021): 2; cf. Lana F. Rakow, "Feminist Historiography and the Field," in The History of Media and Communication Research: Contested Memories, eds. David W. Park and Jefferson Pooley (New York: Peter Lang, 2008); Martina Thiele, "Female Academics in Communication Science and the Post-War Reconstruction Generation in Austria and Germany," in The International History of Communication Study, eds. Peter Simonson and David W. Park (New York: Routledge, 2016).
} 
characteristics, historical continuity, and coherence to members of a group. However, this group may be merely imagined. Collective identity in this case is a construct detached from the memories, values, and orientations of individuals. Normative collective identity concepts are predetermined to serve political interests. ${ }^{11}$

These two perspectives can be discussed in terms of what their (1) analytical value is for historical studies on communication studies. (2) Moreover, knowing that there are reconstructive and prescriptive ways of understanding collective identity can be helpful to classify findings. In this case, prescriptive and reconstructive perspectives are the result of historical analysis. (1) The analytical value of a prescriptive usage is low because this usage aims at pushing a certain normative idea of a collective. Therefore, I suggest applying the reconstructive perspective as an analytical tool. There are two subject matters which can be studied by applying the reconstructive perspective: firstly, collective identities in studies about public communication and secondly, collective identities of communication studies. These two subject matters are described below. (2) A reconstructive understanding will have to classify in which way the discipline has used the concept of collective identity at different moments in history. Has it been the reconstructive or the prescriptive way, or yet another way, and what were the reasons for this? The reconstructive or the prescriptive use of collective identity therefore might be the result of historical analysis.

Arguing that a prescriptive perspective on collective identity is a normative one, shall not point to the conclusion that my whole essay is free of normative charge. Focusing on issues such as exclusion and inclusion, like I do here, is, of course, a normative decision.

\section{Subject Matter 1: Collective Identities in Studies about Public Communication}

In terms of collective identity construction, the media have held "positions of power" because, depending on the particular media system, they have shaped prevailing societal representations of groups and perpetuated cognitive representations of those groups. ${ }^{12} \mathrm{Com}-$ munication studies' work gives insights into how the discipline has been linked to collective identity construction in public communication. But the patterns of social categorization and boundary construction that have appeared in publications are not the only objects of historiography. Such a history could also reveal to what extent research fields such as media usage, media effects, and media content reproduced or questioned the dominant principles of division perpetuated by the media or by politics. Are there recurring ideas, approaches, and methodological principles within the
${ }^{11}$ Assmann, Das kulturelle Gedächtnis, 132; Jürgen Straub, "Personale und kollektive Identität. Zur Analyse eines theoretischen Begriffs," in Identitäten. Erinnerung, Geschichte, Identität, eds. Aleida Assmann and Heidrun Friese (Frankfurt am Main: Suhrkamp, 1998), 98-99, 102.

\footnotetext{
${ }^{12}$ Jake Harwood and Abhik Roy, "Social Identity Theory and Mass Communication Research," in Language as Social Action. Intergroup Communication, eds. Jake Harwood and Howard Giles (New York: Peter Lang, 2005), 191.
} 
"specific symbolic universe"13 of communication studies that legitimated or opposed societal exclusion and inclusion (e.g., regarding class, geography/"first" and "third" worlds, nations, gender, ethnicity)? Using stereotypes has always been integral to the symbolic practices of media audiences in Europe-for instance, cinema audiences. Women, children, or subordinate classes have been ascribed characteristics such as being emotional, pleasure-seeking, and suggestible. Such descriptions were incorporated into early theories on cinema. ${ }^{14}$ Audience studies about socialist countries largely applied citizen/consumer categorizations derived from Western systems. The experiences and living conditions of users in the East were obviously "never made part of this narrative."15 Dichotomies such as citizen/consumer or active/passive defined what was the established ideal at a given moment of history: "What is good, deserves reward, power, privilege."16 They are linked to hegemonic symbolic systems. ${ }^{17}$ To understand the mechanisms of symbolic power, analysis must include who published where, with what habitus, social position, and geopolitical location: Who got to speak for the field and shaped its contours, in which local, national, and global settings? ${ }^{18}$

\section{Subject Matter 2: Collective Identities of Communication Studies}

This perspective sheds light on the way communication studies collectives constructed a "we" for themselves that, for some time, was binding. It gives insights into what past they invented for themselves and which members of these collectives held symbolic power in such self-definitions. "Great men, great events, great places" have been used, for instance, in the North American and Western European context to form a historical canon. ${ }^{19}$ Collective identity construction in the academic world may serve the purpose of self-reflection (one's own cognitive and social principles), of integrating members, and of legitimating the field to the outside. Furthermore, this perspective reveals structures and practices regarding boundary construction and exclusion. Social categories such as class, ethnicity, and gender charged with specific value judgments at different moments in history shaped appointment and employment procedures, curriculum building, distribution of seats and positions in committees and associations, and informal academic networks. ${ }^{20}$ What were the consequences for the institutionalization of perspectives, ideas, and theories? Furthermore, the field was influenced by larger collective identity processes regarding nations and regions. The regionalization of social sciences in Latin America would serve as an example. When "the notion of the Latin American unity" was no longer based on shared colonization aftereffects and common languages but on the ${ }^{13}$ Bourdieu, Language and Symbolic
Power, 124.

\author{
${ }^{14}$ Richard Butsch, "Audiences and \\ Publics, Media and Public Spheres." \\ In The Handbook of Media Audiences, ed. \\ Virginia Nightingale (Chichester and \\ Malden, MA: Wiley-Blackwell, 2011), \\ 156. \\ ${ }^{15}$ Irena Reifová, "A Study in the His- \\ tory of Meaning-making: Watching \\ Socialist Television Serials in the For- \\ mer Czechoslovakia," European Journal \\ of Communication 30, no. 1 (2015), 80. \\ ${ }^{16}$ Richard Butsch, The Making of Amer- \\ ican Audiences. From State to Television, \\ 1750-1990 (Cambridge: Cambridge \\ University Press, 2000), 2. \\ ${ }^{17}$ Bourdieu, Language and Symbolic \\ Power, 132. \\ ${ }^{18}$ Badr and Ganter, "Towards Cos- \\ mopolitan Media and Communication \\ Studies," 2.
}

\begin{abstract}
${ }^{19}$ Rakow, "Feminist Historiography and the Field," 115; cf. Katharina Wischmeyer, "'Ungleich unter Gleichen'. Frauen am Berliner Institut für Publizistik und der Fall Elke Baur," in 'Regierungszeit des Mittelbaus'? Annäherungen an die Berliner Publizistikwissenschaft nach der Studentenbewegung, eds. Maria Löblich and Niklas Venema (Köln: Halem, 2020).
\end{abstract}

\footnotetext{
${ }^{20}$ Dow, "The Lessons of History"; Martina Thiele, "Female Academics in Communication Science."
} 
idea to "make sense of each nation or sub-region," promoted by political movements, a new ideal of "(Latin) Americanism" also shaped ideas regarding cooperation and integration of social scientific communities in different Latin American countries. ${ }^{21}$

\section{An Example from Germany}

The German media discourse on East Germany provides an example of how a prescriptive collective identity in public communication was reproduced in scholarly works. A one-sided, negative interpretation of the German Democratic Republic (GDR) was constructed in the national media after 1989 and has largely prevailed until today. It typically reduced the socialist country to dictatorship, to persons killed at the borders, and to the Fall of the Berlin Wall. ${ }^{22}$ The events of 1989 were framed as the East German way out of "dictatorship" and into "freedom," for the most part excluding the everyday experiences in the GDR. The German reunification was recounted as a story of success. ${ }^{23}$ East Germans became the "others," whose behavior had to be explained to "us," the majoritarian West German society. ${ }^{24}$ Even today, critics say that media coverage about East Germany is pejorative and unbalanced. Its issues have been right-wing radicalism, under-education in terms of democracy, and the inability to cope with a market society. The national press located in West Germany and under West German ownership held the interpretive primacy of these "delegitimating discourses." 25

Central elements of these discourses appeared in communication studies. Insofar as communication studies after the political turn dealt with East Germany at all, publications focused on press concentration and on the adjustment of East German journalists to the requirements and norms of the Western media system. Some examples demonstrate that these sources are worth historicizing. They contain similar descriptions of "the other" German. Methodically, they did not aim at including the remembrances and experiences of East Germans. "In the communities of the former GDR," reads one study, ". . . there is a lack of democratic and participatory traditions." ${ }^{26}$ East German local communication, reads another, was characterized by "a fixation on the state and authority." 27 Another study examined to what extent East German journalists had the "capability to investigate." ${ }^{28}$ It also investigated their "profiles of performance" 29 and whether they could "cope" with the "density of work" that the market organization involved..$^{\circ}$ Book titles at the end of the second decade after reunification still reproduced the dominant narratives regarding 1989 and 1990 (e.g., How the Media Came to Freedom ${ }^{31}$ and Media Freedom after the Political Turn $\left.{ }^{32}\right)$.
${ }^{21}$ Gustavo Sorá and Alejandro Blanco, "Unity and Fragmentation in the Social Sciences in Latin America," in The Social and Human Sciences in Global Power Relations. Socio-Historical Studies of the Social and Human Sciences, eds. Johan Heilbron, Gustavo Sorá and Thibaud Boncourt (Cham: Springer International Publishing, 2009), 128.

${ }^{22}$ Hans-Jörg Stiehler, “ ‘Eine eigenartige Wendung.' Warum die überregionale Presse in Ostdeutschland scheitert. Gespräch mit Hans-Jörg Stiehler," in Wie die Medien zur Freiheit kamen. Zum Wandel der ostdeutschen Medienlandschaft seit dem Untergang der DDR, eds. Michael Haller and Lutz Mükke (Köln: Halem, 2010), 254; Michael Meyen, "Wir haben freier gelebt." Die DDR im kollektiven Gedächtnis der Deutschen (Bielefeld: transcript, 2013).

${ }^{23}$ Markus Böick, Constantin Goschler, and Ralph Jessen, "Die deutsche Einheit als Geschichte der Gegenwart: Einleitung," in Jahrbuch Deutsche Einheit 2020 (Berlin: Ch. Links, 2020); Martin Sabrow, " '1989' als Erzählung” (Bonn: Bundeszentrale für politische Bildung, 2021).

${ }^{24}$ Thomas Ahbe, "Die Ost-Diskurse als Strukturen der Nobilitierung und Marginalisierung von Wissen," in Die Ostdeutschen in den Medien. Das Bild von den Anderen nach 1990, eds. Thomas Ahbe, Rainer Gries, and Wolfgang Schmale (Leipzig: Leipziger Universitätsverlag, 2009), 59-112.

${ }^{25}$ Stiehler, "'Eine eigenartige Wendung,'" 254 .

${ }^{26}$ Beate Schneider and Dieter Stürzebecher, Wenn das Blatt sich wendet. Die Tagespresse in den neuen Bundesländern (Baden-Baden: Nomos, 1998), 212.

${ }^{27}$ Schneider and Stürzebecher, Wenn das Blatt sich wendet, 220.

${ }^{28}$ Claudia Mast, Klaus Haasis, and Matthias Weigert, Medien und Journalismus im Umbruch. Konzepte und Erfahrungen von Medienunternehmen, Verbänden und Redakteuren in den neuen Bundesländern, in Journalismus in den 
The social field structure of communication studies and the habitus of representatives, which can only be described roughly here, help to understand these ascriptions. Throughout the 1990s, new institutes were founded in East Germany. West German scholars were appointed as professors. GDR professors and most academic staff had to leave the institute in Leipzig, which had been the center for journalism education in the GDR. 33 Communication studies after 1989 has been primarily involved in quantitative mass communication research. This paradigm had been dominant in the Federal Republic of Germany since the 1960s. It led the discipline in West Germany out of its crisis after National Socialism by demonstrating allegiance to the United States, the alleged role model of democracy. Walter J. Schütz (1930-2013, a founding member of the West German communication studies' association in 1963, federal ministry official involved in grant decisions, newspaper statistician), remembered that he opposed several times the admission of those people "who had represented the system of media control" to the association. ${ }^{34}$ Altogether, there were limits in the interest of researching GDR media and East German media development. 35

\section{Conclusion}

Communication studies, viewed through the collective identity lens, has its historical narratives about "we" and "the others." These narratives are featured in publications, for instance, about media audiences. Ideas of homogeneity and difference have also been developed for the scholarly community itself. They may enable integration (and communication studies' favorable presentation in the public), but may also lead to exclusion and marginalization. Using the theories of Pierre Bourdieu and Jan Assmann, communication (and communication research) related to collective identities can be understood as social constructs which are formed by symbolic power, habitus, capital, field structures, personal identity, and cultural memory.

The aim of the historiography suggested here is to determine to which symbolic formation of a "we" and "the others," in and outside the media, the discipline has contributed. As such formations have their normative side, such a historiography helps to understand particular power relations within and outside the field. It reveals, furthermore, what degree of autonomy communication studies had and which dependencies it shaped in the course of time. neuen Ländern: ein Berufsstand. zwischen Aufbruch und Anpassung, eds. Frank Böckelmann, Claudia Mast and Beate Schneider (Konstanz: Universitätsverlag, 1994), 256.

${ }^{29}$ Mast, Haasis, and Weigert, Medien und Journalismus im Umbruch, 291.

${ }^{30}$ Mast, Haasis, and Weigert, Medien und Journalismus im Umbruch, 293.

${ }^{11}$ Michael Haller and Lutz Mükke (eds.), Wie die Medien zur Freiheit kamen. Zum Wandel der ostdeutschen Medienlandschaft seit dem Untergang der DDR (Köln: Halem, 2010)

${ }^{2}$ Marcel Machill, Markus Beiler and Johannes Gerstenberg, Medienfreiheit nach der Wende Entwicklung von Medienlandschaft, Medienpolitik und Journalismus in Ostdeutschland (Konstanz: UVK, 2010).

${ }^{33}$ Michael Meyen, "Der Ost-WestGipfel vom Mai 1990," in Biografisches Lexikon der Kommunikationswissenschaft, eds. Michael Meyen and Thomas Wiedemann (Köln: Halem, 2020).

34 Walter J. Schütz, "Ich habe immer von Selbstausbeutung gelebt," in "Ich habe dieses Fach erfunden." Wie die Kommunikationswissenschaft an die deutschsprachigen Universitäten kam, eds. Michael Meyen and Maria Löblich (Köln: Halem, 2007), 55.

${ }^{35}$ Mandy Tröger, Pressefrühling und Profit. Wie westdeutsche Verlage 1989/1990 den Osten eroberten (Köln: Halem, 2019), 35 . 


\section{Bibliography}

Ahbe, Thomas. "Die Ost-Diskurse als Strukturen der Nobilitierung und Marginalisierung von Wissen," in Die Ostdeutschen in den Medien. Das Bild von den Anderen nach 1990, edited by Thomas Ahbe, Rainer Gries, and Wolfgang Schmale, 59-12. Leipzig: Leipziger Universitätsverlag, 2009.

Assmann, Jan. Das kulturelle Gedächtnis. Schrift, Erinnerung und politische Identität in frühen Hochkulturen. München: C. H. Beck, 1992.

Assmann, Jan, and John Czaplicka. "Collective Memory and Cultural Identity." New German Critique 65 (1995): 125-33. https://doi. org/10.2307/488538.

Badr, Hanan and Sarah Anne Ganter. "Towards Cosmopolitan Media and Communication Studies: Bringing Diverse Epistemic Perspectives into the Field." Global Media Journal. German Edition 11, no. I (2021). https://doi.org/10.22032/dbt. 491642021.

Böick, Markus, Constantin Goschler, and Ralph Jessen. "Die deutsche Einheit als Geschichte der Gegenwart: Einleitung." In Jahrbuch Deutsche Einheit 2020. 9-23. Berlin: Christoph Links, 2020.

Bourdieu, Pierre. Language and Symbolic Power. Cambridge: Polity Press, 1992.

Butsch, Richard. The Making of American Audiences. From State to Television, 1750-1990. Cambridge: Cambridge University Press, 2000.

Butsch, Richard. "Audiences and Publics, Media and Public Spheres." In The Handbook of Media Audiences, edited by Virginia Nightingale, 149-68. Malden, MA: Wiley-Blackwell, 2011.

Dow, Bonnie J. “The Lessons of History: Women's Studies in Communication Approaches 40." Women's Studies in Communication 37 (2014): 259-61. https://doi.org/10.1080/07491409.2014. 955431.

Eisenstadt, Shmuel Noah, and Bernhard Giesen. "The Construction of Collective Identity." European Journal of Sociology 36, no. 1 (1995): 72-102. https://doi.org/10.1017/S0003975600007116.

Haller, Michael, and Lutz Mükke, eds. Wie die Medien zur Freiheit kamen. Zum Wandel der ostdeutschen Medienlandschaft seit dem Untergang der DDR. Köln: Halem, 2010.

Harwood, Jake, and Abhik Roy. "Social Identity Theory and Mass Communication Research." In Language as Social Action. Intergroup communication, edited by Jake Harwood and Howard Giles, 189-211. New York: Peter Lang, 2005.

Machill, Marcel, Markus Beiler, and Johannes Gerstenberg. Medienfreiheit nach der Wende Entwicklung von Medienlandschaft, Medienpolitik und Journalismus in Ostdeutschland. Konstanz: UVK, 2010. Mast, Claudia, Klaus Haasis, and Matthias Weigert. "Medien und 
Journalismus im Umbruch. Konzepte und Erfahrungen von Medienunternehmen, Verbänden und Redakteuren in den neuen Bundesländern." In Journalismus in den neuen Ländern: ein Berufsstand. zwischen Aufbruch und Anpassung, edited by Frank Böckelmann, Claudia Mast and Beate Schneider, 231-450. Konstanz: Universitätsverlag, 1994.

Meyen, Michael. "Wir haben freier gelebt." Die DDR im kollektiven Gedächtnis der Deutschen. Transcript. Bielefeld, 2013.

Meyen, Michael. "Der Ost-West-Gipfel vom Mai 199o." In Biografisches Lexikon der Kommunikationswissenschaft, edited by Michael Meyen and Thomas Wiedemann. Köln: Halem, 2020. http: //blexkom. halemverlag.de/ost-west-gipfel.

Pooley, Jefferson, and David W. Park. "Introduction." In The History of Media and Communication Research. Contested Memories, edited by David W. Park and Jefferson Pooley, 1-15. New York: Peter Lang, 2008.

Rakow, Lana F. "Feminist Historiography and the Field." In The History of Media and Communication Research. Contested Memories, edited by David W. Park and Jefferson Pooley, 113-39. New York: Peter Lang, 2008.

Reifová, Irena. "A Study in the History of Meaning-making: Watching Socialist Television Serials in the Former Czechoslovakia." European Journal of Communication 30, no. 1 (2015): 79-94.

Rost, Dietmar. "Reviewed Work(s): Kollektive Identität. Heimliche Quellen einer unheimlichen Konjunktur by Lutz Niethammer." Historical Social Research 28, no. 4 (2003): 188-202.

Sabrow, Martin. "1989" als Erzählung. Bonn: Bundeszentrale für politische Bildung, 2021. http://www.bpb.de/apuz/295464/ 1989 - als - erzaehlung.

Schneider, Beate, and Dieter Stürzebecher. Wenn das Blatt sich wendet. Die Tagespresse in den neuen Bundesländern. Baden-Baden: Nomos, 1998.

Schütz, Walter J. "Ich habe immer von Selbstausbeutung gelebt." In "Ich habe dieses Fach erfunden." Wie die Kommunikationswissenschaft an die deutschsprachigen Universitäten kam, edited by Michael Meyen and Maria Löblich, 33-58. Köln: Halem, 2007.

Simonson, Peter, and David W. Park. "Introduction: On the History of Communication Study." In The International History of Communication Study, edited by Peter Simonson and David W. Park, 1-22. New York: Routledge, 2016.

Simpson, Christopher. "Elisabeth Noelle-Neumann's 'Spiral of Silence' and the Historical Context of Communication Theory." Journal of Communication 46 (1996): 149-73. https://doi.org/10. 1111/j . 1460-2466. 1996. tb01494 . x.

History of Media Studies, vol. 1, 2021 
Sorá, Gustavo, and Alejandro Blanco. "Unity and Fragmentation in the Social Sciences in Latin America." In The Social and Human Sciences in Global Power Relations. Socio-Historical Studies of the Social and Human Sciences, edited by Johan Heilbron, Gustavo Sorá and Thibaud Boncourt, 127-52. Cham: Springer International Publishing, 2009.

Stiehler, Hans-Jörg. " 'Eine eigenartige Wendung.' Warum die überregionale Presse in Ostdeutschland scheitert. Gespräch mit HansJörg Stiehler." In Wie die Medien zur Freiheit kamen. Zum Wandel der ostdeutschen Medienlandschaft seit dem Untergang der DDR, edited by Michael Haller and Lutz Mükke, 248-6o. Köln: Halem, 2010.

Straub, Jürgen. "Personale und kollektive Identität. Zur Analyse eines theoretischen Begriffs." In Identitäten: Erinnerung, Geschichte, Identität, edited by Aleida Assmann and Heidrun Friese, 73-104. Frankfurt am Main: Suhrkamp, 1998.

Thiele, Martina. "Female Academics in Communication Science and the Post-War Reconstruction Generation in Austria and Germany." In The International History of Communication Study, edited by Peter Simonson and David W. Park, 130-50. New York: Routledge, 2016.

Tröger, Mandy. Pressefrühling und Profit. Wie westdeutsche Verlage 1989/1990 den Osten eroberten. Köln: Halem, 2019.

Wahl-Jorgensen, Karin. "Rebellion and Ritual in Disciplinary Histories of U.S. Mass Communication Study: Looking for 'The Reflexive Turn.'" Mass Communication E Society 3, no. 1 (2000): 87-115. https://doi.org/10.1207/S15327825MCS0301_05.

Wendelin, Manuel, and Elisabeth Noelle-Neumann. Biografisches Lexikon der Kommunikationswissenschaft, edited by Michael Meyen and Thomas Wiedemann. Köln: Halem, 2013. http://blexkom. halemverlag.de/elisabeth-noelle-neumann.

Wischmeyer, Katharina. “'Ungleich unter Gleichen.' Frauen am Berliner Institut für Publizistik und der Fall Elke Baur." In "Regierungszeit des Mittelbaus?" Annäherungen an die Berliner Publizistikwissenschaft nach der Studentenbewegung, edited by Maria Löblich and Niklas Venema, 431-50. Köln: Halem, 2020. 